\title{
Comparative Evaluation of Hyperfunction of Thyroid Gland in Women with other Thyroid Disfunctions: Central Bosnia and Herzegovina Experience
}

\author{
Edhem Hasković ${ }^{1}$, Jasmina Marušić ${ }^{2}$, Denis Hasković ${ }^{3}$, Muhamed Fočak ${ }^{1}$, Safija Herenda ${ }^{4}$ \\ ${ }^{1}$ University of Sarajevo, Faculty of Science, Department of Biology, Sarajevo, \\ Bosnia and Herzegovina \\ 2University "Vitez" Vitez, Bosnia and Herzegovina \\ ${ }^{3}$ Clinical Center of the University of Sarajevo, Organizational Unit Clinical Chemistry and Biochemistry, \\ Sarajevo, Bosnia and Herzegovina \\ ${ }^{4}$ University of Sarajevo, Faculty of Science Department of Chemistry, Sarajevo, \\ Bosnia and Herzegovina
}

\section{SUMMARY}

The incidence of thyroid dysfunction in the area of central Bosnia with special reference to hyperthyroidism was being monitored. Considering that there were disagreements among earlier authors and even their contradictory results, the goal was to determine the percentage ratio between the thyroid hyperfunction and other dysfunctions and to identify the degree of correlation between thyroid hormones and the age structure of women. The study included 76 women aged 20 to 82 years with increased values of thyroid hormones and 49 women with reduced values of thyroid hormones. Thirty female patients with baseline thyroid hormone levels comprised a control group. Hyperthyroidism was observed in $60.8 \%$ of women, with the highest percentage of getting ill in their fourth and fifth decade of life (64\%). The monitoring of TSH, FT4 and FT3 hormone values in thyroid dysfunction compared to women with thyroid gland hormone reference values by age groups showed that there was a statistically significant difference in the age group between 40 and 59 years $(p<0.05)$. For the age group of 60 years and older, there was no significant difference $(p>0.05)$. The TSH hormone value and the age of women are positively correlated and mutually dependent $(p<0.05)$. The observed reduction in the thyroid hormone values with an increase in women's age can be considered an adaptation of the organism to the reduced need for energy and represents an important metabolic parameter of the biological process of aging.

Key words: thyroid gland, TSH hormone, FT4 hormone, FT3 hormone

Corresponding author:

Safija Herenda

Email: islamovic.safija@gmail.com 


\section{INTRODUCTION}

Thyroid hormones have long been known for their profound effects on metabolism and cardiovascular function and play a key role in differentiation, growth, metabolism and physiological functions of almost all tissues (1-3). Synthesis and secretion of thyroid hormones is highly regulated by a negative feedback system involving the hypothalamus, pituitary gland and thyroid gland (4). Thyrotropin-releasing hormone (TRH) is a tripeptide that is synthesized in the paraventricular core of the hypothalamus, and binds to the TRH receptors in pituitary tyrotrope. Tata et al. suggest that thyroid hormones may be involved in the regulation of the target gene transcription. In the same paper, T3 treatment of hypothyroid rats induced a rapid increase in liver synthesis, protein synthesis, and mitochondrial oxidetion (5). Two primary thyroid disorders are the state of excessive formation of iodotyronine (hyperthyroidism) and the state of insufficient formation of iodotyroidin (hypothyroidism). According to Souza et al.., thyroid hormones (TH) are potent modulators of lipid metabolism (6). Subclinical hyperthyroidism involves conditions in which TSH values are lowered (suppressed) and the values of T4 (FT4) and T3 (FT3) are normal. Also, subclinical hyperthyroidism results in consequences involving all organ systems; however, it is necessary to focus on changes in the heart, bones and to check the neuropsychiatric status. Determination of T3 (FT3) is important in diagnosing and monitoring of the response to Graves' hyperthyroidism, but also in the diagnosis of toxic adenoma and multinodular toxic dysfunction, since T3 (FT3) is often the first indicator of hyperfunction in these disorders. Unlike subclinical hyperthyroidism, in subclinical hypothyroidism, TSH plasma concentrations are slightly elevated, while the FT4 value is within the reference limits (7). The aim of this study was to examine the degree of frequency of thyroid gland hyperfunction in women in central Bosnia in relation to other thyroid dysfunctions.

\section{MATERIAL AND METHODS}

The study was conducted in the Public Institution "Travnik Hospital", with 30 patients assigned to the control group, with the thyroid hormone reference values, while in 125 women out of 1,164 subjects, elevated or decreased thyroid hormone values were found. All patients were aged 20 to 82 years.

\section{Blood sampling and electrochemilum- inescent method}

Blood for analysis was taken by venipuncture. Determination of the value of the selected biochemical parameters was done on the biochemical analyzer Roche elecsys 1010 which operates on the principle of electrochemiluminescence. The chemiluminescence method is based on reactions in which a portion of the resulting free energy is emitted in the form of electromagnetic radiation. Excitation occurs due to chemical or electrochemical reactions. Light emitting and biological reactions (bioluminescence) have a wide range of analytical applications. The advantage of this method is that it is very sensitive, fast and requires simple procedures (8). Hemiluminiscence is used in iminochromic analyzers to measure extremely low atomic $\left(10-18 \times 10^{23} \mathrm{M}\right)$ and zeptomoral (10-21 zM) concentrations of the analyte.

\section{Statistical analysis}

Descriptive and analytical statistics were used for the analysis of the results of the research, and the analysis and data processing itself was done using statistical programs SPSS 20.0. and the Microsoft Excell 2007 program. The following mathematical statistical indicators were used: arithmetic mean, standard deviation, minimum, maximum, range, $\mathrm{H} 2$ test, Student's test, free linear correlation. The conclusions were made at the level of significance $(\mathrm{p}<0.05)$.

\section{RESULTS}

This study examined a representative sample of 1,164 women who were sent to the laboratory of Hospital Travnik for suspected dysfunction of the thyroid gland by the doctors of family medicine. Of the total sample, 125 women (10.7 \%) had a thyroid disorder, with 76 (60.8 \%) women having thyroid hyperfunction, whereas hipofunction was recorded in 49 (39.2 \%) women. Thirty patients with reference values of thyroid hormone were assigned to the control group. Table 1 shows a statistical evaluation of the results of the obtained thyroid hormone values in patients with benchmark thyroid hormone values taken as a control group.

The average age of control group patients is slightly higher than $43 \pm 9.42$ years. The youngest female in 
the control group was 30 years old and the oldest was 63 years old. The coefficient of variation was $21 \%$, which means that the group was homogeneous. The sample included 30 women who had the following average values of the thyroid hormone: the TSH hormone value for women in the control group was $1.6 \mu \mathrm{UU} / \mathrm{ml}$, the deviation was significant, $1.11 \mu \mathrm{UU} / \mathrm{ml}$. The minimum TSH hormone value was $0.27 \mu \mathrm{UU} / \mathrm{ml}$, while the maxi- mum was $3.98 \mu \mathrm{IU} / \mathrm{ml}$. The average value of the FT4 hormone was $18.46 \mathrm{pmol} / \mathrm{L}$, with a deviation of 3.29 pmol / L, with a range of values of $12.25 \mathrm{pmol} / \mathrm{L}$ to 22 pmol / L. The mean value of FT3 hormone in this group was $5.68 \mathrm{pmol} / \mathrm{L}$, with a deviation of $1.89 \mathrm{pmol} / \mathrm{L}$. The minimum value of FT3 hormone was $3.1 \mathrm{pmol} / \mathrm{L}$ and a maximum of $14.3 \mathrm{pmol} / \mathrm{L}$.

Table 1. Results of thyroid hormone values in the control group

\begin{tabular}{|c|c|c|c|c|}
\hline \multicolumn{5}{|c|}{ Control group $(n=30)$} \\
\hline Parameter & Age & $\begin{array}{c}\mathrm{TSH} \\
0.270-4.20 \\
\mu \mathrm{IU} / \mathrm{ml}\end{array}$ & $\begin{array}{c}\text { FT4 } \\
12.00-22.00 \\
\mathrm{pmol} / \mathrm{L}\end{array}$ & $\begin{array}{c}\text { FT3 } \\
3.10-6.80 \\
\mathrm{pmol} / \mathrm{L} \\
\end{array}$ \\
\hline Arithmetic mean & 43.83 & 1.60 & 18.46 & 5.68 \\
\hline Standard deviation & 9.40 & 1.11 & 3.29 & 1.89 \\
\hline Minimum & 30.0 & 0.27 & 12.50 & 3.10 \\
\hline Maximum & 63.0 & 4.20 & 22.0 & 14.30 \\
\hline Coefficient of variation & 21.00 & 69.00 & 18.00 & 33.00 \\
\hline
\end{tabular}

Table 2. Values of thyroid hormone in female patients with hyperthyroidism

\begin{tabular}{|c|c|c|c|c|}
\hline \multicolumn{5}{|c|}{ Female patients with hyperthyroidism $\quad(n=76)$} \\
\hline Parameter & Age & $\begin{array}{c}\mathrm{TSH} \\
0.270-4.20 \\
\mu \mathrm{IU} / \mathrm{ml}\end{array}$ & $\begin{array}{c}\mathrm{FT} \\
412.00-22.00 \\
\mathrm{pmol} / \mathrm{L}\end{array}$ & $\begin{array}{c}\text { FT3 } \\
3.10-6.80 \\
\mathrm{pmol} / \mathrm{L} \\
\end{array}$ \\
\hline Arithmetic mean & 51.33 & 0.15 & 31.39 & 10.72 \\
\hline Standard deviation & 10.52 & 0.075 & 18.08 & 8.58 \\
\hline Minimum & 28.0 & 0.005 & 11.11 & 3.32 \\
\hline Maximum & 80.0 & 3.51 & 100.01 & 50.01 \\
\hline Coefficient of variation & 21.00 & 50.00 & 56.00 & 80.00 \\
\hline
\end{tabular}

Table 2 shows statistical indicators of the parameters tested for patients with hyperthyroidism. The mean age of patients with hyperthyroidism was $51.33 \pm 10.52$ years. The youngest respondent with hyperthyroidism in this study was 28 years old and the oldest was aged 80. The mean TSH value was $0.15 \mu \mathrm{UU} / \mathrm{ml}$, the minimum value was $0.005 \mu \mathrm{IU} / \mathrm{ml}$, while the maximum value was $3.51 \mu U \mathrm{U} / \mathrm{ml}$. The mean value of FT4 was 31.39 
pmol / L, \pm 18.08 pmol / L. The FT4 hormone value for patients with hyperthyroidism ranged from $11.11 \mathrm{pmol} /$ L to $100.01 \mathrm{pmol} / \mathrm{L}$. The average value of FT3 was 10.72 $\mathrm{pmol} / \mathrm{L}, \pm 8.58 \mathrm{pmol} / \mathrm{L}$, the minimum value was
$3.32 \mathrm{pmol} / \mathrm{L}$, and a maximum of $50.01 \mathrm{pmol} / \mathrm{L}$.

The results of the analysis of the thyroid hormone value between the control group and patients with hyperthyroidism by age groups are given in Table 3 .

Table 3. Statistical evaluation of thyroid gland values by age groups of the control group and women with hyperthyroidism

\begin{tabular}{|c|c|c|c|c|c|}
\hline & & \multicolumn{4}{|c|}{ Female patients with } \\
\hline & & $\begin{array}{c}\text { Control group }(n=30) \\
\bar{x}\end{array}$ & $\begin{array}{c}\text { hyperthyroidism } \\
(\mathrm{n}=76) \\
\overline{\mathbf{x}}\end{array}$ & $\mathrm{T}$ & Sig. \\
\hline \multirow{3}{*}{ 20-39 years } & $\mathrm{TSH}$ & $2.02 \pm 1.65$ & $0.15 \pm 0.75$ & 0.04 & $<0.05$ \\
\hline & FT4 & $17.07 \pm 3.67$ & $44.38 \pm 28.9$ & 0.017 & $<0.05$ \\
\hline & FT3 & $5.02 \pm 1.11$ & $17.06 \pm 14.46$ & 0.049 & $<0.05$ \\
\hline \multirow{3}{*}{ 40-59 years } & $\mathrm{TSH}$ & $1.35 \pm 0.69$ & $0.1 \pm 0.49$ & 0.00 & $<0.05$ \\
\hline & FT4 & $19.1 \pm 3.06$ & $29.04 \pm 14.38$ & 0.022 & $<0.05$ \\
\hline & FT3 & $16.1 \pm 2.29$ & $9.9 \pm 6.52$ & 0.010 & $<0.05$ \\
\hline \multirow{3}{*}{$>60$ years } & $\mathrm{TSH}$ & $1.62 \pm 0.76$ & $0.53 \pm 1.66$ & 0.067 & $>0.05$ \\
\hline & FT4 & $19.48 \pm 2.56$ & $27.16 \pm 11.31$ & 0.457 & $>0.05$ \\
\hline & FT3 & $5.45 \pm 0.61$ & $7.13 \pm 3.84$ & 0.084 & $>0.05$ \\
\hline
\end{tabular}

Table 4. Correlations between age and thyroid hormone values in female patients with hyperthyroidism

\begin{tabular}{l|c|c|c|c|c}
\hline \hline & Parameter & Age & $\begin{array}{c}\text { TSH } \\
0.270-4.20 \\
\mu \mathrm{IU} / \mathrm{ml}\end{array}$ & $\begin{array}{c}\text { FT4 } \\
12.00-22.00 \\
\mathrm{pmol} / \mathrm{L}\end{array}$ & $\begin{array}{c}\text { FT3 } \\
3.10-6.80 \\
\mathrm{pmol} / \mathrm{L}\end{array}$ \\
\hline \multirow{3}{*}{$\begin{array}{l}\text { Pearson's } \\
\text { correlation }\end{array}$} & Age & - & 0.228 & -0.314 & -0.359 \\
& TSH & 0.228 & - & -0.084 & -0.111 \\
& FT4 & -0.314 & -0.084 & - & 0.899 \\
\hline \multirow{3}{*}{$\begin{array}{l}\text { Sig. (1-tailed) } \\
\text { Significance test }\end{array}$} & FT3 & -0.359 & -0.111 & 0.899 & 0.003 \\
& Age & - & 0.024 & 0.234 & 0.169 \\
\hline $\mathrm{N}$ & FSH & 0.024 & - & - & 0.000 \\
\hline \hline
\end{tabular}

Female patients with hyperthyroidism in the age groups 20-39 years and 40-59 years show a statistically significant difference in thyroid hormone values relative to the control group, which is also indicated by the value of $\mathrm{p}<0.05$.

The analyzed parameters in the age group of 60 
and over did not show a statistically significant difference between the control group and the hormone value in female patients with hyperthyroidism ( $p>0.05)$.

In Table 4, Pearson's coefficient of correlation shows that the increase in the age of subjects is in correlation with elevated TSH values of the thyroid hormone.
For the FT4 Pearson's correlation coefficient, the increase in the age of female patients with hyperthyroid causes a decrease in the FT4 hormone value.

The proportion of respondents also has a negative correlation with the values of FT3 hormone, and increased age of the examinees leads to a decrease in the value of FT3 hormones.

Table 5. Values of the thyroid hormone in female patients with hypothyroidism

\begin{tabular}{ccccc}
\hline & Female patients with hypothyroidism & (n $=49)$ & \\
Parameter & Age & TSH & FT4 & FT3 \\
& & $\begin{array}{c}0.270-4.20 \\
\mu \mathrm{IU} / \mathrm{ml}\end{array}$ & $\begin{array}{c}12.00-22.00 \\
\mathrm{pmol} / \mathrm{L}\end{array}$ & $\begin{array}{c}3.10-6.80 \\
\mathrm{pmol} / \mathrm{L}\end{array}$ \\
\hline Arithmetic mean & 55.61 & 32.79 & 10.35 & 3.41 \\
Standard deviation & 12.75 & 27.06 & 4.26 & 1.32 \\
Minimum & 28.0 & 4.45 & 0.891 & 0.4 \\
Maximum & 82.0 & 100 & 24.19 & 6.9 \\
Coefficient of variation & 23.00 & 83.00 & 41.00 & 39.00 \\
\hline \hline
\end{tabular}

Table 6. Values of the thyroid gland hormone by age groups of the control group and female patients with hypothyroidism

\begin{tabular}{|c|c|c|c|c|c|}
\hline & & \multicolumn{4}{|c|}{ Female patients with } \\
\hline & & $\begin{array}{l}\text { Control group }(n=30) \\
\qquad \bar{x}\end{array}$ & $\begin{array}{l}\text { hypothyroidism } \\
(\mathrm{n}=49) \\
\overline{\mathbf{x}}\end{array}$ & $\mathbf{T}$ & Sig. \\
\hline \multirow{3}{*}{ 20-39 years } & $\mathrm{TSH}$ & $2.02 \pm 1.65$ & $62.26 \pm 33.22$ & 0.037 & $<0.05$ \\
\hline & FT4 & $17.07 \pm 3.67$ & $9.07 \pm 1.92$ & 0.137 & $>0.05$ \\
\hline & FT3 & $5.02 \pm 1.11$ & $3.76 \pm 1.97$ & 0.153 & $>0.05$ \\
\hline \multirow{3}{*}{ 40-59 years } & $\mathrm{TSH}$ & $1.35 \pm 0.69$ & $29.51 \pm 24.33$ & 0.015 & $<0.05$ \\
\hline & FT4 & $19.1 \pm 3.06$ & $11.32 \pm 3.92$ & 0.000 & $<0.05$ \\
\hline & $\mathrm{FT}_{3}$ & $16.1 \pm 2.29$ & $3.6 \pm 1.07$ & 0.000 & $<0.05$ \\
\hline \multirow{3}{*}{$>60$ years } & $\mathrm{TSH}$ & $1.62 \pm 0.76$ & $27.13 \pm 23.4$ & 0.755 & $>0.05$ \\
\hline & FT4 & $19.48 \pm 2.56$ & $9.06 \pm 5.19$ & 0.067 & $>0.05$ \\
\hline & FT3 & $5.45 \pm 0.61$ & $2.92 \pm 1.42$ & 0.099 & $>0.05$ \\
\hline
\end{tabular}

Table 5 shows the values of thyroid hormone in female patients with hypothyroidism. It can be seen that the mean age of female patients with hypothyroidism was $55.61 \pm 12.75$ years. The youngest female in the stu- 
dy was 28 years old and the oldest 82 years old. The sample included 49 women who had the following values of the tested parameters. The mean TSH hormone value was $32.79 \pm 27.06 \mu \mathrm{IU} / \mathrm{ml}$. The minimum value was $4.45 \mu \mathrm{IU} / \mathrm{ml}$, while the maximum was $100 \mu \mathrm{IU}$ / $\mathrm{ml}$. The mean value of FT3 hormone was $10.35 \pm 4.26$ pmol / L. The FT4 hormone values varied from 0.891 pmol / L to $24.19 \mathrm{pmol} / \mathrm{L}$. The mean value of the FT3 hormone was $3.41 \mathrm{pmol} / \mathrm{L}, \pm 1.32 \mathrm{pmol} / \mathrm{L}$. The minimum value of FT3 hormone was $0.4 \mathrm{pmol} / \mathrm{L}$ and the maximum value was $6.9 \mathrm{pmol} / \mathrm{L}$.

The obtained $t$ test values in the age group 20 to 39 years show that there was a statistically significant difference in the TSH thyroid hormone values in female patients with hypothyroidism compared to the control group (Table 6). Respondents with hypothyroidism had a significantly higher value of TSH thyroid hormone, which is also indicated by the value of $(\mathrm{p}<0.05)$.

The results of the test show that subjects with hypothyroidism in the age group of 20 to 39 years did not show a significant difference in the values of FT4 and FT3 in relation to the control group ( $p>0.05)$.

In the age group 40 to 59 years, there was a significant difference in the value of all tested hormones of female patients with hypothyroidism compared to the control group, which is also indicated by the value of $\mathrm{p}<$ 0.05 .

In the age group of 60 years and over, there was no significant difference in the value of the tested parameters between the two analyzed groups $(\mathrm{p}>0.05)$.

\section{DISCUSSION}

In our study, it was found that the incidence of hyperthyroidism in women is higher than the incidence of hypothyroidism. Multi-year surveys in the United States show that the incidence of hyperthyroidism is relatively stable, and in England, the estimated frequency of hyperthyroidism is significantly higher (1-2 \%). The overall prevalence of hyperthyroidism (earlier and current) was $2.7 \%$ in women and $0.25 \%$ in males. In our study, it turned out that women with hyperthyroidism have significantly higher thyroid hormone values compared to the hormone value of the thyroid gland of the control group, which is probably the consequence of the disease itself. Our results are in agreement with the results of Messina et al. who claim that the plasma concen- tration of total T4 and T3 is affected by changes in the binding protein level, especially TBG, while the concentration of free FT4 and FT3 hormone changes in TBG does not have a significant effect. This increase in total $\mathrm{T} 4$ and $\mathrm{T} 3$ in women with aging, without changes in the level of free hormones, indicates indirectly that it is not a consequence of increased thyroid hormone secretion, but increased secretion of TBG in women in menopause (9).

In our study, we have shown that there is a statistically significant difference in the incidence of hyperthyroidism in relation to the age group. Hyperthyroidism most commonly occurs in the fourth and fifth decade of life, amounting to $60.8 \%$. Vanderpump et al., in the same age group, showed that hypothyroidism is not associated with ischemic heart disease, while Hak et al., who examined the correlation between subclinical hypothyroidism in elderly women and atherosclerosis of the aorta and myocardial infarction, showed that subclinical hypothyroidism is a potent risk factor for atherosclerosis of the aorta and myocardial infarction $(10,11)$. The American Association of Clinical Endocrinologists recommends that TSH test be performed in all women over 40 years of age in order to detect early thyroid disorders as studies have shown that $10 \%$ of women in this age group have undiagnosed thyroid disease $(12,13)$. These results are in line with the results obtained in our studies which show that thyroid dysfunction in most cases occurs between 40 and 59 years of age. This age category belongs to $64 \%$ of respondents indicating that this thyroid dysfunction coincides with the onset of menopause in women, and that the changes in thyroid hormone values are in correlation with aging. This study also found that there was a statistically significant difference in the levels of TSH, FT4 and FT3 hormones in the age group 20-59 years in hyperthyroidism, and in the age group over 60 years there was no statistically significant difference in relation to the hormone values of the control group of women. In our study, we confirmed that there was a statistically significant difference in the incidence of women with thyroid gland defect in relation to the age of the female control group. A statistically significant difference in the value of TSH hormones in the age group of 20 to 39 years was established, while for FT4 and FT3 hormone, a statistically significant difference was not found for this age group and for the group over 60 years of age. For the age group 40-59 years, statistical significance was established for all three parameters. Unlike relatively unchanged T4 concentrations, it was 
found that $\mathrm{T} 3$ values decrease with aging, which was confirmed by a large number of authors and by our research as well. Sawin et al. have proven that hormone T3 diminishes in women over 80 years of age, and in men in their seventh decade of life (14). Harman et al. found that the concentration of FT4 was significantly lower in elderly subjects, which is also consistent with the results of Lipson et al. who showed that serum T4 levels were lower in women over the age of 60 but not in men (15). These data agree with our study in which we have shown that there is no statistically significant difference in the values of FT4 and FT3 hormones in women with thyroid dysfunction compared to women in the control group over 60 years. Most authors have reported in their studies that serum T3 values decreased with age, and FT3 values increased with age and that serum concentration of $\mathrm{T} 3$ was nevertheless significantly reduced in healthy elderly people (15). These results are approximate to our results, as our research has shown that the values of FT4 and FT3 hormones correlate with age groups. The observed decreased thyroid hormone concentration, which was accompanied by an increase in TSH hormone concentrations in relation to age groups, indicates that the mechanism of negative feedback between the circulating thyroid hormone and pituitary gland is not disturbed, i.e. the sensitivity (resistance) of tireotroph of the pituitary gland to a negative feedback relationship with thyroid hormones has not been reduced.

\section{CONCLUSION}

$\mathrm{TSH}$, as an independent parameter of the thyroid dysfunction assessment, is not the best indicator in hypothyroidism and hyperthyroidism. Studies have shown that the value of thyroid hormone in women with hyperthyroidism varies considerably by age categories compared to the control group, except in women over 60 years of age. The symptoms of hyperthyroidism occuring in female patients of a certain age are visible changes on the skin and are among the basic diagnostic indicators. Also, cardiac frequency and impact volume are increased, circulation is accelerated, and capillaries are enlarged. The values of FT4 and FT3 hormons in women with hypothyroidism are significantly reduced, while TSH hormone values are significantly increased in relation to the hormone value of the control group; however, these differences are not statistically significant. Studies have shown that the value of thyroid hormone in women with hypothyroidism varies considerably by age categories compared to the control group, except in women over 60 years of age. On the basis of the obtained epidemiological data, it can be concluded that there is no valid epidemiological data on the incidence of hyperthyroidism in our country compared to other thyroid dysfunctions, and that it is necessary to introduce a national thyroid gland disease regimen with a recommendation for screening hyperthyroidism in the target groups: women, pregnant women and cardiovascular patients. 


\section{References}

1. Klemperer JD, Ojamaa K, Klein I. Thyroid hormone therapy in cardiovascular disease, Prog Cardiovasc Dis 1996; 38: 329-36. https://doi.org/10.1016/S0033-0620(96)80017-X

2. Klein I, Ojamaa K. Thyroid hormone and the cardiovascular system, J Endocrinol 2001;344:501-9.

3. Paul MY. Physiological and molecular basis of thyroid hormone action, Physiol Rev 2001; 81:1097-142. https://doi.org/10.1152/physrev.2001.81.3.1097

4. Shupnik MA, Ridgway EC, Chin WW. Molecular biology of thyrotropin. Endocr Rev 1989;10: 459-75. https://doi.org/10.1210/edrv-10-4-459

5. Tata JR, Ernster L, Lindberg O, et al. The action of thyroid hormones at the cell level. Biochem J 1963; 86: 408-28. https://doi.org/10.1042/bj0860408

6. Souza LL, Cordeiro A, Oliveira LS, et al. Thyroid hormone contributes to the hypolipidemic effect of polyunsaturated fatty acids from fish oil: in vivo evidence for cross talking mechanisms, J Endocrinol 2011; 211:65-72.

\section{https://doi.org/10.1530//OE-11-0142}

7. Refetoff S. Resistance to thyroid hormone. In: Braverman LE, et al. The Thyroid. A Fundamental and Clinical Text, $9^{\text {th }}$ Edition. Philadelphia: Lippincott Williams \& Wilkins, 2005: 1109-29.

8. Kricka Lj. Chemiluminescent and bioluminescent techniques. Clin Chem 1991; 37:1472-81.

9. Messina G, Viceconti N, Trinti B. Variations in the anatomy and physiology of the thyroid gland in old age. Recenti Prog Med 1997; 88:281-6.
10. Vanderpump MP, Tunbridge VM, French JM et al. The development of ischemic heart disease in relation to autoimmune thyroid disease in a 20-year Followup stady of and English community. Thyroid 1996; 6: 155-60

11. Hak AE, Pols HA, Visser TJ, et al. Subclinical hypothyroidism is an independent risk factor for atherosclerosis and myocardial infarction in elderly women: the Rotterdam Study. Ann Intern Med 2000; 132:270-8. https://doi.org/10.7326/0003-4819-132-4-200002150$\underline{00004}$

12. Surks MI, Chopra IJ, Maraish CN, et al. American Thyroid Association guidelines for use of laboratory test in thyroid disorders, JAMA 1990; 263:1529-32. https://doi.org/10.1001/jama.1990.03440110095035

13. Garber JR, Cobin RH, GHarib H, et al. Clinical practice guidelines for hypothyroidism in adults: Cosponsored by the American Association of Clinical Endocrinologists and the American Thyroid Association. Thyroid 2012; 22:1200-35. https://doi.org/10.1089/thy.2012.0205

14. Sawin CT, Bigos ST, Land S, Bacharach P. The aging thyroid: Relationship between elevated serum thyrotropin level and thyroid antibodies in elderly patients, Am J Med 1985; 79:591-5 https://doi.org/10.1016/0002-9343(85)90056-7

15. Lipson RH, Dimov SS, Cai JY, et al. J. Mass - resolved two-photon spectra of $\mathrm{Kr}_{2}$ Chem Phys 1995; 102: 5881. https://doi.org/10.1063/1.469322 


\title{
Komparativna evaluacija hiperfunkcije štitne žlezde kod žena sa drugim disfunkcijama štitne žlezde: iskustvo u centralnoj Bosni
}

\author{
Edhem Hasković ${ }^{1}$, Jasmina Marušić ${ }^{2}$, Denis Hasković ${ }^{3}$, Muhamed Fočak ${ }^{1}$, Safija Herenda \\ ${ }^{1}$ Univerzitet u Sarajevu, Prirodno-matematički fakultet Odsjek za biologiju, Sarajevo, Bosna i Hercegovina \\ ${ }^{2}$ Sveučilište/Univerzitet "Vitez", Vitez, Bosna i Hercegovina \\ ${ }^{3}$ Klinički centar Univerziteta u Sarajevu, Organizaciona jedinica Klinička hemija i biohemija, Sarajevo, \\ Bosna i Hercegovina \\ ${ }^{4}$ Univerzitet u Sarajevu, Prirodno-matematički fakultet, Odsjek za hemiju, Sarajevo, Bosna i Hercegovina
}

\section{SAŽETAK}

U ovom radu praćena je incidenca tiroidne disfunkcije na području centralne Bosne. $S$ obzirom na to da su postojala neslaganja i protivrečnosti rezultata u ranijim istraživanjima, glavni cilj bio je odrediti odnos između hiperfunkcije štitne žlezde i drugih poremećaja organizma, te odrediti stepen korelacije hormona štitne žlezde i dobne strukture žena. Istraživanje je obuhvatilo 76 žena u dobi od 20 godina do 82 godine s povećanim vrednostima hormona i 49 žena sa smanjenim vrednostima hormona štitne žlezde. Uzorak od 30 pacijentkinja sa referentnim vrednostima hormona uzet je kao kontrolna grupa. Hipertireoza je zabeležena kod $60,8 \%$ žena, pri čemu je najveći postotak bolesti registrovan u četvrtoj i petoj deceniji života (64 \%). Praćenje vrednosti hormona TSH, FT4 i FT3 pri disfunkciji štitne žlezde u odnosu na žene sa referentnim vrednostima hormona prema dobnim grupama pokazalo je statistički značajnu razliku u dobnoj grupi od 40 do 59 godina $(\mathrm{p}<0,05)$. U dobnoj grupi od 60 i više godina nije bilo značajne razlike ( $p>0,05)$. Vrednost hormona TSH i dob žena u pozitivnoj su korelaciji i međusobno su zavisni $(p<0,05)$. Promatrano smanjenje vrednosti hormona štitne žlezde s povećanjem dobi žena može se smatrati prilagođavanjem organizma na smanjenu potrebu za energijom i predstavlja važan metabolički parametar biološkog procesa starenja.

Ključne reči: tireoidna žlezda, hormon TSH, FT4 hormon, FT3 hormon 